National and Global Petroleum Assessment

\title{
Assessment of Undiscovered Conventional Oil and Gas Resources in the Lower Paleozoic of the Williston Basin Province, 2020
}

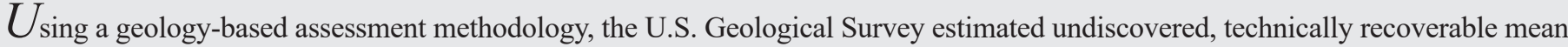
resources of 83 million barrels of oil and 351 billion cubic feet of gas in lower Paleozoic strata of the Williston Basin Province, North Dakota, Montana, and South Dakota.

\section{Introduction}

The U.S. Geological Survey (USGS) quantitatively assessed the potential for undiscovered, technically recoverable conventional oil and gas resources in lower Paleozoic total petroleum systems (TPSs) of the Williston Basin Province in North Dakota, Montana, and South Dakota (fig. 1; Anna, 2013). Six geologic assessment units (AUs) were defined within the Ordovician Winnipeg TPS and Ordovician Red River TPS in the lower Paleozoic stratigraphic section. Each AU was assessed for undiscovered conventional oil, gas, and natural gas liquids.

The current structure of the Williston Basin Province began forming during the Middle Ordovician when the reactivation of a complex set of Proterozoic faults provided accommodation space for Ordovician Winnipeg Group sandstone and shale deposits.

Continued fault movement through the Late Ordovician and Silurian resulted in deposition of shallow marine carbonates of the Red River, Stony Mountain, and Stonewall Formations of the Bighorn Group and the Interlake Formation of Baillie (1951). Organic-rich shales within the Icebox Formation of the Winnipeg Group and within the Red River Formation are interpreted as the main petroleum source rocks (Osadetz and Snowden, 1995; Jarvie, 2001; Khan and others, 2006; Lillis, 2012; Nesheim, 2017a, b).

The Winnipeg Fairway Reservoirs AU, Red River Fairway Reservoirs AU, and Interlake-Stonewall-Stony Mountain Fairway Reservoirs AU were defined to encompass an area within the central part of the basin (fairway) in which fluid migration is predominantly vertical rather than lateral (fig. 1). All oil and gas production from the Ordovician Winnipeg TPS and Ordovician Red River TPS are from within the fairway. The geologic model for the three fairway AUs is that oil and gas generated from Icebox Formation and Red River Formation organic-rich shales migrated into Cambrian sandstones of the Deadwood and the Winnipeg or up faults into dolomitic reservoirs within the Red River, Stony Mountain, Stonewall, and Interlake Formations (Longman and others, 1992; Nesheim, 2017a).

In contrast, the Winnipeg Eastern Margin Reservoirs AU, Red River Eastern Margin Reservoirs AU, and the Interlake-StonewallStony Mountain Eastern Margin Reservoirs AU were defined to include areas to the east and southeast of the fairway where lateral migration of oil or gas sourced from Icebox Formation or Red River Formation organic-rich shales might have formed oil or gas accumulations. Evidence of lateral migration of oil from the fairway is provided by Lantry Field (fig. 1), which was discovered in 1970 about 100 miles southeast of Red River Formation fairway production and was shut in after production of 140,000 barrels of oil (Bogle and others, 1998). Key input data for the six conventional AUs are shown in table 1 .

\section{Undiscovered Resources Summary}

The USGS quantitatively assessed undiscovered conventional oil, gas, and natural gas liquid resources within the lower Paleozoic strata of the Williston Basin Province, in North Dakota, Montana, and South Dakota (table 2). The fully risked mean totals are 83 million barrels of oil (MMBO) with an F95-F5 fractile range from 44 to $144 \mathrm{MMBO}, 351$ billion cubic feet of gas (BCFG) with an F95-F5 range from 178 to 632 BCFG, and 45 million barrels of natural gas liquids (MMBNGL) with an F95-F5 range from 21 to 82 MMBNGL.

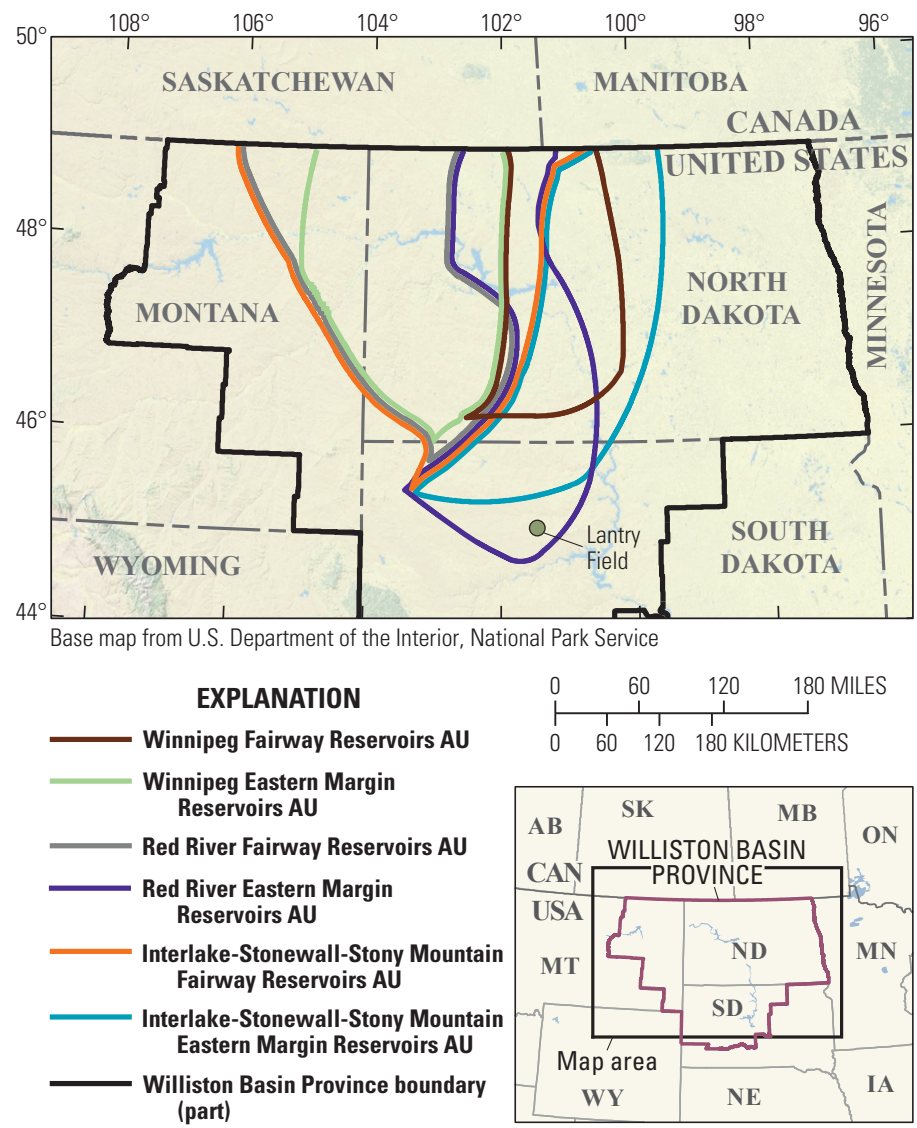

Figure 1. Map showing the location of six assessment units (AUs) in the lower Paleozoic of the Williston Basin Province, North Dakota, Montana, and South Dakota. Adjacent lines indicate a shared boundary at the outermost line. 
Table 1. Key input data for six conventional assessment units in the lower Paleozoic of the Williston Basin Province, North Dakota, Montana, and South Dakota.

[Gray shading indicates not applicable. AU, assessment unit; MMBO, million barrels of oil; BCFG, billion cubic feet of gas]

\begin{tabular}{|c|c|c|c|c|c|c|c|c|c|c|c|c|}
\hline \multirow{2}{*}{$\begin{array}{l}\text { Assessment input data- } \\
\text { Conventional AUs }\end{array}$} & \multicolumn{4}{|c|}{ Winnipeg Fairway Reservoirs AU } & \multicolumn{4}{|c|}{ Winnipeg Eastern Margin Reservoirs AU } & \multicolumn{4}{|c|}{ Red River Fairway Reservoirs AU } \\
\hline & Minimum & Median & Maximum & Calculated mean & Minimum & Median & Maximum & Calculated mean & Minimum & Median & Maximum & Calculated mean \\
\hline Number of oil fields & 1 & 3 & 9 & 3.2 & 1 & 2 & 6 & 2.1 & 1 & 50 & 100 & 51.2 \\
\hline Number of gas fields & 1 & 20 & 40 & 20.5 & 1 & 4 & 12 & 4.3 & 1 & 10 & 20 & 10.3 \\
\hline Size of oil fields (MMBO) & 0.5 & 0.7 & 8 & 0.9 & 0.5 & 0.7 & 5 & 0.8 & 0.5 & 0.7 & 5 & 0.83 \\
\hline Size of gas fields (BCFG) & 3 & 5 & 48 & 6.3 & 3 & 5 & 30 & 5.8 & 3 & 5 & 48 & 6.3 \\
\hline AU probability & 1.0 & & & & 0.5 & & & & 1.0 & & & \\
\hline \multirow{2}{*}{$\begin{array}{l}\text { Assessment input data- } \\
\text { Conventional AUs }\end{array}$} & \multicolumn{4}{|c|}{ Red River Eastern Margin Reservoirs AU } & \multicolumn{4}{|c|}{$\begin{array}{c}\text { Interlake-Stonewall-Stony Mountain } \\
\text { Fairway Reservoirs AU }\end{array}$} & \multicolumn{4}{|c|}{$\begin{array}{c}\text { Interlake-Stonewall-Stony Mountain } \\
\text { Eastern Margin Reservoirs AU }\end{array}$} \\
\hline & Minimum & Median & Maximum & Calculated mean & Minimum & Median & Maximum & Calculated mean & Minimum & Median & Maximum & Calculated mean \\
\hline Number of oil fields & 1 & 15 & 45 & 16.0 & 1 & 25 & 50 & 25.6 & 1 & 10 & 30 & 10.6 \\
\hline Number of gas fields & 1 & 5 & 15 & 5.3 & 1 & 5 & 15 & 5.3 & 1 & 2 & 6 & 2.1 \\
\hline Size of oil fields (MMBO) & 0.5 & 0.7 & 12 & 1.0 & 0.5 & 0.7 & 10 & 0.9 & 0.5 & 0.7 & 12 & 1.0 \\
\hline Size of gas fields (BCFG) & 3 & 5 & 72 & 6.8 & 3 & 5 & 72 & 6.8 & 3 & 5 & 72 & 6.8 \\
\hline AU probability & 0.5 & & & & 1.0 & & & & 0.5 & & & \\
\hline
\end{tabular}

Table 2. Results for six conventional assessment units in the lower Paleozoic of the Williston Basin Province, North Dakota, Montana, and South Dakota.

[Results shown are fully risked estimates. F95 represents a 95-percent chance of at least the amount tabulated; other fractiles are defined similarly. Gray shading indicates not applicable. MMBO, million barrels of oil; BCFG, billion cubic feet of gas; NGL, natural gas liquids; MMBNGL, million barrels of natural gas liquids]

\begin{tabular}{|c|c|c|c|c|c|c|c|c|c|c|c|c|c|c|}
\hline \multirow{3}{*}{$\begin{array}{l}\text { Total petroleum systems } \\
\text { and assessment units (AUs) }\end{array}$} & \multirow{3}{*}{$\begin{array}{c}\text { AU } \\
\text { prob- } \\
\text { ability }\end{array}$} & \multirow{3}{*}{$\begin{array}{l}\text { Accumu- } \\
\text { lation } \\
\text { type }\end{array}$} & \multicolumn{12}{|c|}{ Total undiscovered resources } \\
\hline & & & \multicolumn{4}{|c|}{ Oil (MMBO) } & \multicolumn{4}{|c|}{ Gas (BCFG) } & \multicolumn{4}{|c|}{ NGL (MMBNGL) } \\
\hline & & & F95 & F50 & F5 & Mean & F95 & F50 & F5 & Mean & F95 & F50 & F5 & Mean \\
\hline \multicolumn{15}{|c|}{ Ordovician Winnipeg Total Petroleum System } \\
\hline \multirow{2}{*}{$\begin{array}{l}\text { Winnipeg Fairway } \\
\text { Reservoirs AU }\end{array}$} & \multirow{2}{*}{1.0} & Oil & 1 & 3 & 6 & 3 & 1 & 3 & 6 & 3 & 0 & 0 & 0 & 0 \\
\hline & & Gas & & & & & 80 & 125 & 191 & 129 & 6 & 9 & 14 & 10 \\
\hline \multirow{2}{*}{$\begin{array}{l}\text { Winnipeg Eastern Margin } \\
\text { Reservoirs AU }\end{array}$} & \multirow{2}{*}{0.5} & Oil & 0 & 0 & 3 & 1 & 0 & 0 & 3 & 1 & 0 & 0 & 0 & 0 \\
\hline & & Gas & & & & & 0 & 0 & 38 & 12 & 0 & 0 & 3 & 1 \\
\hline \multicolumn{15}{|c|}{ Ordovician Red River Total Petroleum System } \\
\hline \multirow{2}{*}{$\begin{array}{l}\text { Red River Fairway } \\
\text { Reservoirs AU }\end{array}$} & \multirow{2}{*}{1.0} & \begin{tabular}{l|l} 
Oil \\
\end{tabular} & 28 & 41 & 60 & 42 & 28 & 41 & 60 & 42 & 3 & 4 & 6 & 5 \\
\hline & & Gas & & & & & 38 & 62 & 100 & 64 & 7 & 12 & 19 & 13 \\
\hline \multirow{2}{*}{$\begin{array}{l}\text { Red River Eastern Margin } \\
\text { Reservoirs AU }\end{array}$} & \multirow{2}{*}{0.5} & Oil & 0 & 4 & 24 & 8 & 0 & 4 & 24 & 8 & 0 & 1 & 3 & 1 \\
\hline & & Gas & & & & & 0 & 9 & 60 & 18 & 0 & 2 & 12 & 4 \\
\hline \multirow{2}{*}{$\begin{array}{l}\text { Interlake-Stonewall-Stony } \\
\text { Mountain Fairway } \\
\text { Reservoirs AU } \\
\end{array}$} & \multirow{2}{*}{1.0} & Oil & 15 & 23 & 35 & 24 & 16 & 25 & 39 & 26 & 2 & 2 & 4 & 2 \\
\hline & & Gas & & & & & 15 & 32 & 70 & 36 & 3 & 6 & 14 & 7 \\
\hline \multirow{2}{*}{$\begin{array}{l}\text { Interlake-Stonewall-Stony } \\
\text { Mountain Eastern Margin } \\
\text { Reservoirs AU }\end{array}$} & \multirow{2}{*}{0.5} & Oil & 0 & 3 & 16 & 5 & 0 & 3 & 16 & 5 & 0 & 0 & 2 & 1 \\
\hline & & Gas & & & & & 0 & 3 & 25 & 7 & 0 & 1 & 5 & 1 \\
\hline $\begin{array}{l}\text { Total undiscovered } \\
\text { conventional resources }\end{array}$ & & & 44 & 74 & 144 & 83 & 178 & 307 & 632 & 351 & 21 & 37 & 82 & 45 \\
\hline
\end{tabular}

\section{For More Information}

Assessment results are also available at the USGS Energy Resources Program website at https://www.usgs. gov/energy-and-minerals/ energy-resources-program/.

\section{Williston}

\section{Basin Province Assessment Team}

Christopher J. Schenk, Tracey J. Mercier, Cheryl A. Woodall, Geoffrey S. Ellis, Thomas M. Finn, Phuong A. Le, Kristen R. Marra, Heidi M. Leathers-Miller, and Ronald M. Drake II

\section{References Cited}

Anna, L.O., 2013, Geologic assessment of undiscovered oil and gas in the Williston Basin Province, Montana, North Dakota, and South Dakota, chap. 3 of U.S. Geological Survey Williston Basin Province Assessment Team, comps., Assessment of undiscovered oil and gas resources of the Williston Basin Province of North Dakota, Montana, and South Dakota, 2010: U.S. Geological Survey Digital Data Series DDS-69-W, 56 p. [Also available at https://pubs.usgs.gov/dds/dds-069/dds-069-w/.]

Baillie, A.D., 1951, Silurian geology of the Interlake area: Manitoba, Manitoba Department of Mines and Natural Resources, Mines Branch publication $50-01,82 \mathrm{p}$.

Bogle, R.W., Longman, M.W., and Single, E.L., 1998, Nature of the Red River reservoir at Lantry field, Williston Basin, South Dakota, in Slatt, R.M., ed., Compartmentalized reservoirs in Rocky Mountain basins: Rocky Mountain Association of Geologists, p. 171-188.

Jarvie, D.M., 2001, Williston Basin petroleum systems —-Inferences from oil geochemistry and geology: The Mountain Geologist, Rocky Mountain Association of Geologists v. 38, no. 1, p. 19-41.

Khan, D.K., Rostron, B.J., Margitai, Z., and Carruthers, D., 2006, Hydrodynamics and petroleum migration in the Upper Ordovician Red River
Formation of the Williston Basin: Journal of Geochemical Exploration, v. 89 , no. $1-3$, p. $179-182$.

Lillis, P.G., 2012, Review of oil families and their petroleum systems of the Williston Basin: The Mountain Geologist, Rocky Mountain Association of Geologists, v. 50, no. 1, p. 5-31.

Longman, M.W., Fertel, T.G., and Stell, J.R., 1992, Reservoir performance in Ordovician Red River Formation, Horse Creek and South Horse Creek fields, Bowman County, North Dakota: American Association of Petroleum Geologists Bulletin, v. 76, no. 4, p. 449-467.

Nesheim, T.O., 2017a, Stratigraphic and geochemical investigation of kukersites (petroleum source beds) within the Ordovician Red River Formation, Williston Basin: American Association of Petroleum Geologists Bulletin, v. 101, no. 9, p. $1445-1471$.

Nesheim, T.O., 2017b, Stratigraphic correlation and thermal maturity of kukersite petroleum source beds within the Ordovician Red River Formation: North Dakota Geological Survey, Report of Investigation No. 118, 48 p.

Osadetz, K.G., and Snowden, L.R., 1995, Significant Paleozoic source rocks in the Canadian Williston Basin-Their distribution, richness, and thermal maturity (southeastern Saskatchewan and southwest Manitoba): Geological Survey of Canada Bulletin 487, $60 \mathrm{p}$. 